\title{
IMPACT OF BRAND ASSOCIATION, BRAND IMAGE \& BRAND LOYALTY ON BRAND EQUITY
}

\author{
Muhammad Habib Dada ${ }^{1}$
}

\begin{abstract}
The most important determinants of brand equity are brand image and brand loyalty. These both critical elements effect customers thought process and build up their perception of the brand. The main objective of this research study is to investigate the critical association between brand association, brand image and loyalty and how they impact brand equity. In order to achieve research intentions, a model reflecting the effect of brand association, brand image and brand loyalty on brand equity was conceptualized. Hypotheses were formulated to assess the relationship between the variables and their impact on the dependent variable. The study adopted a quantitative approach and data were analyzed through structural equation model SEM to assess the correlation. The study findings demonstrate that brand associations, brand loyalty and brand image have a positive effect on brand equity. The study provides brand managers with key insights to enrich the equity of their brands.
\end{abstract}

Keywords: Brand Loyalty; Brand Association; Brand Equity; Brand Image.

\section{INTRODUCTION}

The brand equity concern in marketing is discussed widely and is one of the main marketing tools for the firms to set the standards in the market and to maintain those standards, firms need to capitalize and increased its brand equity on regular basis. This topic is focused on the Brand Equity and how its effect with the other independent variables. Brand Equity add or subtract the value of Brand for the firm (Aaker, 2009). It seems that most of the opinions are that Brand Equity will increased the profitability of the firms and as a result the consumer are agreed to pay for the specific brand is because of the Brand Name which is created with the help of

\footnotetext{
${ }^{1}$ muhammadhabibdada@gmail.com
} 
Brand Equity (Jayswal \& Vora, 2019). For every firm, this is the core objective to increase the Brand Value and firms continuously engaged to increase the brand image in the market.

After consumers, the second most important element for a firm is their brand (Alhaddad, 2014a). The researcher focused on the several other variables which influence the Brand Equity to increase the organization's revenue. The main purpose of the organizations to focus on the Brand Equity is to check how it is important for the firms and how Brand Association, Brand Image and Brand Loyalty influence the Brand Equity as it did in the past. Also to measure Brand Equity the performance and the Brand awareness also its dimension (Severi \& Ling, 2013). But we want to check the brand Equity on Brand Awareness, Brand Image and Brand Loyalty.

Nowadays it is observed that more often or not consumers purchase brands through social media. It is mostly seen as consumers are not satisfied with the product that is available on the social media. They believe the actual problem is the difference in quality between the one that displayed on the website and the other that is delivered to the consumer and the ideal condition is that they see the product in web is as it as they received.

\section{RESEARCH QUESTIONS}

Q1: Which variables have impact on the brand equity?

Q2: Which variable has the positive impact on brand equity?

Q3: Which Variable has the negative impact on brand equity?

Q4: Which variable has the highest impact on brand equity?

\section{OBJECTIVES OF STUDY}

- To check the relation between Brand Association and Brand Equity

- To check the relation between Brand Image and Brand Equity

- To check the relation between Brand Loyalty and Brand Equity

\section{SIGNIFICANCE OF THE STUDY}


This study is related to the researchers and marketers who want to know how brand equity influences on and how firms used it as their USP's to enhance the profits and how they achieved organizational goals. I want to analyze and evaluate how Brand Association, Brand Image and Brand Loyalty impact the Brand Equity. How these variables can make consumer to think and how consumers have the association with the Brand and at what consent they measure Brand Image and Brand Loyalty and how they evaluate it in order to continue purchase the same Brand. The study is useful for the readers and researchers who wants to do research in future in t similar topic.

\section{LITERATURE REVIEW}

\section{Brand Equity}

Brand equity is the top line concept when talking about the marketing. Brand equity refers to the quality of a brand that reflect how a brand gives consistent results to the consumers and firm as well. It is the more important concept as and it is applied by the all the firms to create the value of their brands. The brand equity might be known as "the increased in the brand consistent performance and availability the product known itself as a brand" (Alhaddad, 2014a). Also one researcher define Brand equity as "the various impact of brand knowledge on the consumer reactions in that brand market" (Alhaddad, 2014a). Brand equity may elaborated in many ways, one can say that "the strength of a brand that is already available in the existing market is co related with the company's both (marketing and financial) beliefs and having its quality brand assets, brand awareness with association, its loyalty and having the quality of brand" (Aaker, 2009). It is also described as "the attitude, behavior and perception in the consumer's mind increases the sales of the brand and earn higher profits in the market" (Alhaddad, 2014a). As the consumer gives positive response to the brands on the basis of the brand quality and its image that is built in other consumers related to the brand that has never happen before (Farquhar, 1989). Due to the variance in consumer minds, brand equity also shifts as consumer purchasing specific product (Aaker, 2009). According to the quality of Customer's understanding, the brand equity can be measured (Severi \& Ling 2013). Brand equity makes the firm more valuable along with their customers (Yoo, Donthu, and Lee, 2000).

\section{Brand Association}


The Brand association might be made through the help of benefits, attitudes and attributes (Severi, Ling, \& Nasermoadeli, 2014). Brand association is liked the thing which strongly connected with the brand performance (Atilgan, Aksoy, and Akinci 2005). Brand association plays its role and collect data as an instrument to measure the brand extension (Severi \& Ling, 2013). The definition of brand association is very well known by the consumer and it already in their thoughts and increasing brand awareness for consumer will directly increase consumer attention towards the specific brand (Emari, Jafari, and Mogaddam 2012). Brand Association can also create the brand loyalty of the particular brand (Severi \& Ling, 2013). To create the brand association, customer should have the knowledge of brand first (Jayswal and Vora 2019). The Brand association create path for consumer to purchase more and increased the value of the firm along with it as well. The brand association impacts many more different advantages that helps for the particular brand (Atilgan et al. 2005).

\section{Impact of Brand Association on Brand Equity}

Brand Association and Brand Equity are correlated with each other because the association of brand will increase the overall brand performance (Severi \& Ling, 2013). If there is a high brand equity it means consumers have the high association with the particular brand and it identifies that brand association is one of the core factor in building the brand equity (Atilgan et al. 2005). It also described as the Brand Association creates the positive impact in order to make efficient brand equity (Severi, Ling, \& Nasermoadeli, 2014). In the customer based brand equity, brand association also as important as other factors in the marketing strategies (Jayswal and Vora 2019). Brand awareness is correlated with the brand association and both have direct impact on each other if Brand awareness up, Brand association also goes up and if Brand Association higher, it indicates that Brand equity also higher and it is seeing by the trademark of commitment and desired (Severi, Ling, \& Nasermoadeli, 2014).

\section{H1: Brand Association has the positive and direct impact on Brand Equity}

\section{Brand Image}

Brand image is largely seen in the all the definitions of marketing (Alhaddad, 2014a). If the brand having superior brand image over their competitor then it definitely helps for the brand to increase the brand equity (Severi \& Ling, 2013). In today's world, almost all the firms focus to build Brand Image of their Brand because they know if they succeed to build the good image then it directly gives advantage to their business and they might think for Brand Extension 
(Emari et al. 2012). In order to create the strong roots of the brands, the Brand Image plays the most crucial role in it (Alhaddad, 2014a). Also proposes that customer reaction and their decisions is also based on the Brand image of that Brand. It is also proved by the research that consumer's decision and their attitude towards Brand is also created by Brand Image (Severi, Ling, \& Nasermoadeli, 2014). When consumer wants to make decision between the different alternative Brands, they surely examined all brands on the basis of their Brand Image (Alhaddad, 2014a).

\section{Impact of Brand Image on Brand Equity}

The Brand image is related to the Brand equity and described as if consumer have the Brand Image of specific Brand in his mind either its positive or negative it will create the direct and positive effect on Brand Equity and Brand image is the important thing that influence product Brand Equity (Severi \& Ling, 2013). It also explained as Brand Image and the Brand attitude have both the effects either positive or negative on effect on Brand Equity (Alhaddad, 2014a). Also Brand Image always shows the direct relation with Brand Equity in almost all the scenarios (Alhaddad, 2014a).

\section{H2: Brand Image has the positive relation with the Brand Equity}

\section{Brand Loyalty}

Brand Loyalty is one of the core things in marketing when firms objective to earn profit because it increases performance of the brand in order to gain maximum revenue. Brand Loyalty influences consumer's decision to buy similar product every time and it also has the strength to convert the buyer from the alternative product (Severi \& Ling, 2013). Brand Loyalty also described as the "consumer's first choice to purchase the specific brand compare to the other alternatives" (Emari et al. 2012). Brand loyalty is defined as the essential thing which added or increased the value of the particular brand (Severi \& Ling, 2013). The Important and main advantages of Brand Loyalty to the organization or the company is to retain the old consumers and also developed new one as well, it enhance the brand extension, their price per share also increased along with the minimize the cost and also create brand more powerful in the market (Alhaddad, 2014a). Brand loyalty is the thing which engage consumers with the current brand and if there is increased in the product price the consumer don't shift to the competitor brand because of having Brand Loyalty of that Brand (Emari et al. 2012). It is due to the Brand Loyalty that consumer purchases the same Brand every time he or she purchases. Although, 
many times customer may face contingency factors that disturb him to buy the same Brand. But if the consumer still wants to continue with the same brand, it is because of the Brand Loyalty (Emari et al. 2012).

\section{Impact of Brand Loyalty on Brand Equity}

According to the Brand Loyalty definition it says that Brand loyalty is more often or not is recognized as the essential dimension of Brand Equity and there is a positive relationship between the Brand Loyalty and Brand Equity (Atilgan et al. 2005). Brand Loyalty is the core tool of Brand Equity because with the help of this tool, brand equity will enhance dramatically and it also increases firm's goodwill in the market along with the market share and improve their image as well (Emari et al. 2012). Due to the influence of Brand Loyalty in consumer mind, the Brand increased the retention rate and it increases the Brand Equity for the continue basis and that's why the researchers always believe that Brand Loyalty is the common reason behind the success of Brand Equity (Severi \& Ling, 2013).

\section{H2: Brand Loyalty has the positive relation with the Brand Equity}

\section{CONCEPTUAL FRAMEWORK}

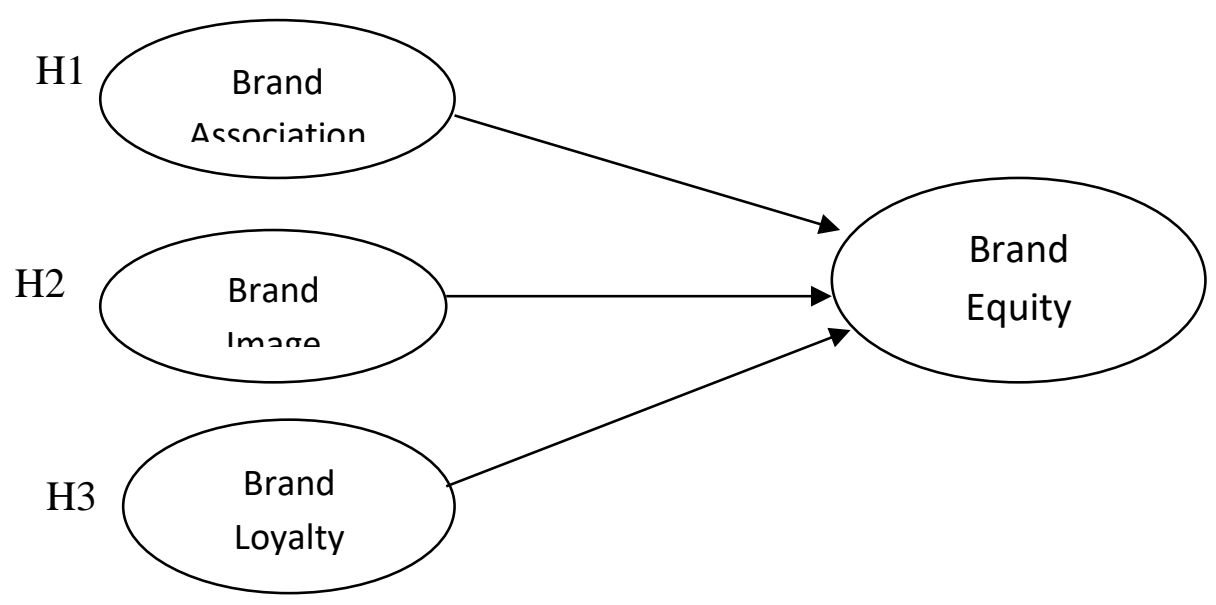




\section{RESEARCH HYPOTHESIS}

\begin{tabular}{|c|c|c|c|}
\hline S. No & Hypothesis & Reference & Article Title \\
\hline H1 & $\begin{array}{l}\text { Brand Association has } \\
\text { a positive impact on } \\
\text { Brand Equity }\end{array}$ & $\begin{array}{l}\text { (Severi \& Ling, 2014) } \\
\text { (Yoo \& Lee, 2005) } \\
\text { (Emari et al. 2012) }\end{array}$ & $\begin{array}{l}\text { 1) The Mediating Effects of } \\
\text { Brand Association, Brand } \\
\text { Loyalty, Brand Image and } \\
\text { Perceived Quality on Brand } \\
\text { Equity. } \\
\text { 2) An Examination of Selected } \\
\text { Marketing Mix Elements and } \\
\text { Brand Equity. } \\
\text { 3) The mediatory impact of } \\
\text { brand loyalty and brand image on } \\
\text { brand equity }\end{array}$ \\
\hline H2 & $\begin{array}{l}\text { Brand Image has a } \\
\text { positive impact on } \\
\text { Brand Equity }\end{array}$ & $\begin{array}{l}\text { (Severi \& Ling, 2014) } \\
\text { (Emari et al. 2012) } \\
\text { (Alhaddad, 2014b) }\end{array}$ & $\begin{array}{l}\text { 1) The Mediating Effects of } \\
\text { Brand Association, Brand } \\
\text { Loyalty, Brand Image and } \\
\text { Perceived Quality on Brand } \\
\text { Equity. } \\
\text { 2) The mediatory impact of } \\
\text { brand loyalty and brand image on } \\
\text { brand equity } \\
\text { 3) The effect of brand image and } \\
\text { brand loyalty on brand equity }\end{array}$ \\
\hline H3 & $\begin{array}{l}\text { Brand Loyalty has a } \\
\text { positive impact on } \\
\text { Brand Equity }\end{array}$ & $\begin{array}{l}\text { (Severi \& Ling 2014) } \\
\text { (Yoo et al. 2000) } \\
\text { (Emari et al. 2012) } \\
\text { (Alhaddad, 2014b) }\end{array}$ & $\begin{array}{l}\text { 1) The Mediating Effects of } \\
\text { Brand Association, Brand } \\
\text { Loyalty, Brand Image and } \\
\text { Perceived Quality on Brand } \\
\text { Equity. } \\
\text { 2) An Examination of Selected } \\
\text { Marketing Mix Elements and } \\
\text { Brand Equity } \\
\text { 3) The mediatory impact of } \\
\text { brand loyalty and brand image on } \\
\text { brand equity } \\
\text { 4) The effect of brand image and } \\
\text { brand loyalty on brand equity }\end{array}$ \\
\hline
\end{tabular}

\section{RESEARCH METHODOLOGY}

A descriptive study approach is used in this research because the research is depending on the characteristics of variables and the analysis should be on the basis of the result of variables. In this study research is doing hypothesis testing and variables relation on each other is influencing the outcome of Research. The research is also basic in nature because the current problem is already faced by the previous researcher as well. In Previous research the 
information is already available related to this topic and already lot of research is conducted related to this topic.

\section{Research Technique}

The technique used in this research is primary and secondary both as we collect the data through questionnaire that is the primary way and also taking help of articles as well. So, both techniques is used in this research to gather the data. Moreover, cross sectional studies is conducted because the data is collected at one time from each member of the population and not collected from same member more than one. Correlational analyses will be conducted to examine the relationship between IVs and DV.

\section{Population \& Sample}

Convenient and non-probability Sampling technique is used in this research because we collected the data through questionnaire with the help of Google Form. Furthermore, a sample of business students from IoBM was drawn as respondents of the study.

\section{Reliability Test}

Reliability test shows the accuracy of the data and it tells how data is accurate.

\begin{tabular}{|l|l|}
\hline \multicolumn{2}{|l|}{ Reliability Statistics } \\
\hline Cronbach's Alpha & N of Items \\
\hline 0.877 & 5 \\
\hline Brand Loyalty & \\
\hline
\end{tabular}

\begin{tabular}{|l|l|}
\hline \multicolumn{2}{|l|}{ Reliability Statistics } \\
\hline Cronbach's Alpha & N of Items \\
\hline 0.779 & 3 \\
\hline Brand Image
\end{tabular}




\begin{tabular}{|l|l|}
\hline \multicolumn{2}{|l|}{ Reliability Statistics } \\
\hline Cronbach's Alpha & 4 \\
\hline 0.781 & N Items \\
\hline Brand Association & \\
\hline
\end{tabular}

\begin{tabular}{|l|l|}
\hline \multicolumn{2}{|l|}{ Reliability Statistics } \\
\hline Cronbach's Alpha & N of Items \\
\hline 0.865 & 4 \\
\hline Brand Equity \\
\hline
\end{tabular}

The reliability test shows that all the variables in my research are reliable because in all the reliability test it shows the value of more than 0.7 , which declare that all the variables in the research are reliable.

\section{RESULTS}

\section{Descriptive Statistics}

\begin{tabular}{|l|l|l|l|l|l|}
\hline & $\mathrm{N}$ & Minimum & Maximum & Mean & Std. Deviation \\
\hline Brand_Association & 54 & 1.75 & 5.00 & 3.7870 & 0.74512 \\
\hline Brand_Image & 54 & 2.33 & 5.00 & 3.8580 & 0.69621 \\
\hline Brand_Loyalty & 54 & 1.80 & 5.00 & 3.7306 & 0.83363 \\
\hline Brand_Equity & 54 & 1.75 & 5.00 & 3.7176 & 0.88761 \\
\hline Valid N (listwise) & 54 & & & & \\
\hline
\end{tabular}




\section{Inferential Statistics}

\begin{tabular}{|c|c|c|c|c|c|}
\hline \multicolumn{6}{|l|}{ Correlations } \\
\hline & & $\begin{array}{l}\text { Brand_ } \\
\text { Equity }\end{array}$ & $\begin{array}{l}\text { Brand_ } \\
\text { Association }\end{array}$ & $\begin{array}{l}\text { Brand_ } \\
\text { Image }\end{array}$ & $\begin{array}{l}\text { Brand_ } \\
\text { Loyalty }\end{array}$ \\
\hline \multirow[t]{3}{*}{ Brand_Equity } & $\begin{array}{l}\text { Pearson } \\
\text { Correlation }\end{array}$ & 1 & $.531 * *$ & $.532 * *$ & $.597 * *$ \\
\hline & Sig. (2-tailed) & & 0.000 & 0.000 & 0.000 \\
\hline & $\mathrm{N}$ & 54 & 54 & 54 & 54 \\
\hline \multirow[t]{3}{*}{$\begin{array}{l}\text { Brand_Associat } \\
\text { ion }\end{array}$} & $\begin{array}{l}\text { Pearson } \\
\text { Correlation }\end{array}$ & $.531 * *$ & 1 & $.632 * *$ & $.681 * *$ \\
\hline & Sig. (2-tailed) & 0.000 & & 0.000 & 0.000 \\
\hline & $\mathrm{N}$ & 54 & 54 & 54 & 54 \\
\hline \multirow[t]{3}{*}{ Brand_Image } & $\begin{array}{l}\text { Pearson } \\
\text { Correlation }\end{array}$ & $.532 * *$ & $.632 * *$ & 1 & $.678 * *$ \\
\hline & Sig. (2-tailed) & 0.000 & 0.000 & & 0.000 \\
\hline & $\mathrm{N}$ & 54 & 54 & 54 & 54 \\
\hline \multirow[t]{3}{*}{ Brand_Loyalty } & $\begin{array}{l}\text { Pearson } \\
\text { Correlation }\end{array}$ & $.597 * *$ & $.681 * *$ & $.678 * *$ & 1 \\
\hline & Sig. (2-tailed) & 0.000 & 0.000 & 0.000 & \\
\hline & $\mathrm{N}$ & 54 & 54 & 54 & 54 \\
\hline
\end{tabular}

**. Correlation is significant at the 0.01 level (2-tailed).

On the basis of Correlation analysis, the sig value is 0.00 of all the variables which shows there is a correlation between all the variables. 


\section{Hypothesis Assessment Summary}

\begin{tabular}{|l|l|l|l|l|}
\hline \multicolumn{4}{|l|}{ Model Summary } \\
\hline Model & R & R Square & Adjusted R Square & Std. Error of the Estimate \\
\hline 1 & $.633 \mathrm{a}$ & 0.401 & 0.365 & 0.70709 \\
\hline
\end{tabular}

On the basis of Model Summary, there is $63.3 \%$ Correlation between the variables and R square interprets that $40 \%$ variation in Brand Equity is explained by the model (Brand Loyalty).

\begin{tabular}{|l|l|l|l|l|l|l|}
\hline \multicolumn{2}{|l|}{ ANOVA $^{\mathrm{a}}$} \\
\hline Model & & Sum of Squares & df & Mean Square & F & Sig. \\
\hline 1 & Regression & 16.757 & 3 & 5.586 & 11.172 & $.000 \mathrm{~b}$ \\
\hline & Residual & 24.998 & 50 & 0.500 & & \\
\hline & Total & 41.756 & 53 & & & \\
\hline
\end{tabular}

On the basis of ANOVA, it is explained that there is the significant relationship between the overall variable (including all independent and dependent variables) because it has the sig value of 0.00 which marginally less than 0.05 .

\begin{tabular}{|l|l|l|l|l|l|l|}
\hline Coefficients & & $\begin{array}{l}\text { Unstandardized } \\
\text { Coefficients }\end{array}$ & & $\begin{array}{l}\text { Standardized } \\
\text { Coefficients }\end{array}$ & t & Sig. \\
\hline & & B & $\begin{array}{l}\text { Std. } \\
\text { Error }\end{array}$ & Beta & & \\
\hline 1 & (Constant) & 0.628 & 0.582 & & 1.080 & 0.285 \\
\hline & Brand_Association & 0.209 & 0.188 & 0.176 & 1.116 & 0.270 \\
\hline & Brand_Image & 0.229 & 0.200 & 0.180 & 1.146 & 0.257 \\
\hline $\begin{array}{l}\text { a. Dependent } \\
\text { Variable: } \\
\text { Brand Equity }\end{array}$ & Brand_Loyalty & 0.379 & 0.177 & 0.356 & 2.141 & 0.037 \\
\hline
\end{tabular}

On the basis of regression analysis, the interpretations of hypothesis are as follows:

\section{H1: Brand Association Vs Brand equity}


There is an insignificant relationship between Brand Association and Brand Equity because the sig value is greater than 0.05 , which interprets that there is no relation between these variables means null hypothesis is accepted and Alternative rejected.

\section{H1: Brand Image Vs Brand equity}

There is an insignificant relationship between Brand Image and Brand Equity because the sig value is 0.25 which is greater than 0.05 , which interprets that there is no relation between these variables means null hypothesis is accepted and Alternative rejected.

\section{H1: Brand Loyalty Vs Brand equity}

There is the Significant relationship between Brand Loyalty and Brand Equity because the sig value is 0.03 which is less than 0.05 and beta is 0.37 which interprets that there is the Significant and positive relationship between Brand Loyalty and Brand equity. And it declares that Positive Alternative hypothesis is accepted while null hypothesis is rejected.

\section{DISCUSSION}

On the basis of overall findings, it is discussed and evaluated that Brand Equity plays the important role in the Businesses to increase the relation between the firms and their consumers. The Research discussed that Brand Equity is depend only on the Brand Loyalty and it shows Brand equity will change if Brand Loyalty changes. So, on the basis of finding, firms need to focus on the Loyalty of their Brand, and they need to make marketing strategies that enhance the Firm's Brand Loyalty in the market. So, firms need to focus on the Brand Loyalty to increase the Brand Equity because if firms maintain and enhance the Brand Equity then their consumer will never use competitor product. On the other hand, the other two independent variables Brand Association and Brand Image don't show the significant relationship with Brand Equity. Although, previous researchers already mentioned that there is a relationship between Brand Image and Brand Equity. But it might be possible because of the limitations that we possess. We only conducted data through Business Students who are studying in universities in Karachi. So, we have to face financial constraint, time constraint, student's unavailability and most importantly student mood which directly effects the dependent variable. 


\section{CONCLUSION}

The findings say that out of three independent variables, only Brand Loyalty has the significant and positive relationship with Brand Equity compare to the rest of two. And it influence the $40 \%$ change in the Brand Equity is due to the Brand Loyalty. So, it evaluates and conclude that Brand Loyalty has the core thing and most importantly first thing in mind when firms consider Brand equity as their strength. Similarly, on the other hand, brand Image and Brand Association creates no impact and have no influence on the Brand Equity, because their sig value is greater than 0.05, it only consider it as the marketing strategy to improve the Brand Equity. Now it is concluded that only Brand Loyalty has the significant relationship and the highest relationship as well.

\section{RECOMMENDATIONS AND FUTURE RESEARCH DIRECTIONS}

The future research should contain and cover most of the population and cover a large sample size. Also, recommendation to marketing students is that this is the topic that is highly related to the marketing, so students who want to do major in market, kindly do some vast research in the same topic. Because as a marketing person, nowadays marketing strategies are very unique and creative. Companies are more focus on the revenue and it also help freshers specially to gain the in-depth learning. 


\section{REFERENCES}

Aaker, D. A. (2009). Managing brand equity. Simon and Schuster.

Alhaddad, A. (2014a). The effect of brand image and brand loyalty on brand equity. International Journal of Business and Management Invention, 3(5), 28-32.

Alhaddad, A. (2014b). Does price awareness matter to brand equity? European Journal of Economics, Finance and Administrative Sciences, 65(1), 20-26.

Atilgan, E., Aksoy, Ş., \& Akinci, S. (2005). Determinants of the brand equity: A verification approach in the beverage industry in Turkey. Marketing intelligence \& planning.

Emari, H., Jafari, A., \& Mogaddam, M. (2012). The mediatory impact of brand loyalty and brand image on brand equity. African Journal of Business Management, 6(17), 56925701.

Farquhar, P. H. (1989). Managing brand equity. Marketing research, 1(3).

Jayswal, M., \& Vora, P. (2019). Impact of brand association on brand equity with specific focus on advergames in India. Journal of Creative Communications, 14(3), 271-284.

Severi, E., \& Ling, K. C. (2013). The mediating effects of brand association, brand loyalty, brand image and perceived quality on brand equity. Asian Social Science, 9(3), 125.

Severi, E., Ling, KC, \& Nasermoadeli, A. (2014). The impacts of electronic word of mouth on brand equity in the context of social media. International Journal of Business and Management, 9 (8), 84-96.

Yoo, B., \& Lee, S. H. (2005). Do counterfeits promote genuine products?. Hofstra University, Hempstead, $N Y$.

Yoo, B., Donthu, N., \& Lee, S. (2000). An examination of selected marketing mix elements and brand equity. Journal of the academy of marketing science, 28(2), 195-211. 
Journal of Marketing Strategies, Volume 3, Issue 1, January 2021

\section{APPENDIX}

Questionnaire

\begin{tabular}{|c|c|c|c|}
\hline Variable Name & S.NO & Scaling & Reference \\
\hline \multirow{4}{*}{ Brand Association } & 1 & \multirow{4}{*}{1 to 5 Scale } & \multirow{4}{*}{ (Severi \& Ling 2014) } \\
\hline & 2 & & \\
\hline & 3 & & \\
\hline & 4 & & \\
\hline \multirow{3}{*}{ Brand Image } & 5 & \multirow{3}{*}{1 to 5 Scale } & \multirow{3}{*}{ (Severi \& Ling, 2013) } \\
\hline & 6 & & \\
\hline & 7 & & \\
\hline \multirow{5}{*}{ Brand Loyalty } & 8 & \multirow{5}{*}{1 to 5 Scale } & \multirow{5}{*}{ (Severi \& Ling, 2013) } \\
\hline & 9 & & \\
\hline & 10 & & \\
\hline & 11 & & \\
\hline & 12 & & \\
\hline \multirow{4}{*}{ Brand Equity } & 13 & \multirow{4}{*}{1 to 5 Scale } & \multirow{4}{*}{ (Yoo et al. 2000b) } \\
\hline & 14 & & \\
\hline & 15 & & \\
\hline & 16 & & \\
\hline
\end{tabular}

